\title{
Türkiye'de Sektörel Eşitsizlikler ve Sayısal Bölünme İlişkisi
}

Hüseyin FIDAN, Department of Industrial Engineering, Faculty of Engineering, Mehmet Akif Ersoy University, Turkey; e-mail: hfidan@mehmetakif.edu.tr

Halil ŞEN, Department of Industrial Engineering, Faculty of Engineering, Mehmet Akif Ersoy University, Turkey; e-mail: halilsen@mehmetakif.edu.tr

\section{Sectoral Inequalities and Relations with the Digital Divide in Turkey}

\begin{abstract}
Inequalities are the leading factors that effect the social and economic structure negatively. In the context of inequalities, personal, regional and global dimensions of income differences are investigated, rarely sectoral analysis in researches. Aim of the study is that determining of intersectoral and intrasectoral inequality levels and relations by using indicators of number of employees, wages, production value, added value as well as having computers, internet usage and having web page. Gini method has used to calculate the level of inequalities and in correlation analysis to determine relationships between inequalities. In analysis result, it has found that maximum intersectoral inequality level is in production value and the lowest in computer usage.
\end{abstract}

Keywords

JEL Classification Codes :

\section{Information Systems, Sectoral Inequalities, Digital Divide, Lorenz} Curve, Gini Coefficients.

D63, O33.

\section{Öz}

Eşitsizlikler sosyal ve ekonomik yapıyı olumsuz etkileyen faktörlerin başında gelmektedir. Eşitsizlikler bağlamında kişisel, bölgesel ve küresel boyutta, gelir eşitsizliklerin incelendiği araştırmalarda, sektörel analizlere nadiren rastlanmaktadır. Bu çalışmada, çalışan sayısı, ücretler, üretim değeri ve katma değer göstergelerinin yanı sıra bilgisayar ve internet kullanımları ile web sayfası sahipliğinde, sektörler arası ve sektör içi eşitsizlik düzeylerinin ve eşitsizlikler arası ilişkilerin belirlenmesi amaçlanmaktadır. Eşitsizlik seviyelerinin belirlenmesinde Gini yöntemi, eşitsizlikler arasındaki ilişkileri belirlemek için korelasyon analizi kullanılmıştır. Analiz sonucunda sektörler arası eşitsizliklerin en fazla üretim değerlerinde, en düşük bilgisayar kullanımlarında olduğu tespit edilmiştir. 
Fidan, H. \& H. Şen (2017), “Türkiye'de Sektörel Eşitsizlikler ve

Sayısal Bölünme İlișkisi”, Sosyoekonomi, Vol. 25(32), 31-50.

\section{Giriş}

Toplumların en büyük problemlerinden olan eşitsizliklerin temelinde, gelir dağılımındaki dengesizlikler yatmaktadır. Dengesizlikler içerisinde en fazla irdelenen kavram, kişiler arasındaki gelir eşitsizlikleridir. Siyasi ve sosyal istikrarsızların sebebi olarak kabul edilen ve küresel bir problem olan gelir eşitsizlik seviyeleri, 1970'li yıllardan başlayarak sürekli artış eğilimindedir (OECD, 2008; Selim vd., 2014: 21). Gelir eşitsizilikleri ile ilgili önemli bir çalışma olan OECD’nin "Divided We Stand: Why Inequality Keeps Rising" isimli raporunda, fakir ve zenginler arasindaki gelir eşitsizliklerinin son otuz yıldır sürekli arttığ 1 ve ilerleyen zamanlarda artış eğiliminin devam edeceği vurgulanmaktadır (OECD, 2011). Bu nedenle ulusal ve uluslararası birçok kuruluş tarafından araştırma konusu olan gelir dengesizlikleri gelişmiş, gelişmekte olan ve gelişmemiş ülkeler arasındaki farklılıkları ortaya koymak için kullanılan bir parametre niteliğindedir. Ekonomik işleyişi doğrudan etkileyen gelir eşitsizlikleri ile ilgili çalışmalar genellikle bölgesel, ulusal ve uluslararası çerçevede, kişisel gelir farklılıkları üzerine yapılmaktadır. Ancak, ekonomik yapının, sektörel yapı ile yakından ilişkili olduğu düşünülürse, sektörler arası ve sektör içi eşitsizlikler üzerine daha fazla çalışmanın yapılması önem arz etmektedir.

Sosyal, bölgesel, politik, teknolojik ve ekonomik nedenlere bağlı oluşan sektörel farklılıklar, ekonomik yapıyı etkileyen başlıca unsurlar arasındadır (Kraftova vd., 2011: 459). Bu farklılıkları ortaya koymak için sektörlerin üretim değerleri, ücret ve istihdam düzeyleri, GSMH içindeki payları, ihracat oranları, ARGE harcamaları, teknoloji kullanım seviyeleri gibi göstergeler kullanılmaktadır. Sektörel üretim değerleri, istihdam seviyesi ve ücret gibi eşitsizliklerin kaynağını belirleyen faktörler ile doğrudan ilişkili olduğu için önemli bir parametre olarak görülmektedir (Galbraith \& Hale, 2007: 4). Sektör çalışanlarına ödenen ücretler arasındaki farklılıklar, bazı sektörlerin milli gelirden aldıkları payların azalmasına ve çalışanların yüksek ücretlerin ödendiği sektörlere yönelmesine neden olmaktadır (Deininger \& Squire, 1998: 275; Hoffmann \& Shi, 2013). Sektörel kaymaların sonucu olarak öne çıkan sektörler daha fazla üretim gerçekleştirerek üretim değerleri, çalışan sayıları ve ücretler ile ilgili sektörel farklılıkların oluşmasına neden olmaktadır (Ngai \& Pissarides, 2007: 438). Diğer taraftan, sektörler arası farklılıklar kadar, sektör içi eşitsizlikler de önemlidir. Thewissen, Wang ve Vliet (2013: 20)'e göre, eşitsizlik düzeyleri her sektöre göre farklılık gösteren sektör içi eşitsizlikler, sektörler arası eşitsizliklerden daha ciddi boyutlarda olabilmektedir. Sektörler arası ve sektör içi dengesizlikler, kaynakların eşit dağılımına engel oluşturarak ekonomiler üzerinde olumsuz etkiler ortaya çıkmasına, refah düzeyinin azalmasına ve ekonomik krizlere yol açmaktadır (Blais vd., 1990: 381).

Sektörel eşitsizliklerin ölçülmesi için genel olarak sektörel büyüklük, üretim değeri, çalışan sayısı, ortalama ücret seviyesi gibi göstergeler kullanılmaktadır. Gelir dağılımı üzerine yoğun araştırmaların yapıldığı Türkiye'de, sektörler arası eşitsizlikler yoğun olarak ücret seviyeleri çerçevesinde incelenmektedir. Sektörel analizlerin yapıldığı çalışmalarda Varyans ayrıştırma, Theil indeksi, Gini katsayıları başta olmak üzere çeşitli ölçüm yöntemlerinin kullanıldığı ve sektörlerin tarım, sanayi, hizmet olarak üç genel grup altında ele alındığı görülmektedir (Filiztekin \& Çelik, 2010; Öztürk, 2012; Taştan \& Akar, 2013). 
Sektör içi eşitsizliklerin incelendiği çalışmalara ise fazla rastlanmamaktadır. Ancak sektörel yapıyı şekillendirdiğinden dolayı sektör içi eşitsizlikler, sektörler arası eşitsizliklerin kaynağını oluşturmaktadır. Bu bağlamda sektörler arası eşitsizliklerin yanı sıra, sektör içi eşitsizliklerin de incelenmesi önem arz etmektedir. Bu çalışmada, Nace Rev.2 ile sınıflandırılan Türkiye'deki sektörler arası ve sektör içi eşitsizliklerin belirlenmesi ile aralarındaki ilişkinin tespit edilmesi amaçlanmıştır. Çalışan sayıları, ücretler, üretim değerleri, faktör maliyetlerine göre katma değerleri, bilgisayar kullanımı, internet kullanımı ve web sayfa sahipliği değişkenleri kullanılarak, sektörler arası ve sektör içi eşitsizliklerin belirlenmesine çalışılmıştır. Eşitsizlik düzeylerinin belirlenmesinde Gini yöntemi, eşitsizlikler arasındaki ilişkilerin belirlenmesinde ise korelasyon analizi kullanılmıştır. TÜİK'ten elde edilen veriler kullanılarak yapılan analiz sonrası, sektörler arası eşitsizlik seviyesinin, sektör içi eşitsizliklerden daha yüksek olduğu belirlenmiştir. Bilgi ve iletişim teknolojilerine sahip olma ve kullanım düzeylerindeki farklılıklar olarak tanımlanan sayısal bölünme (OECD, 2001), tüm sektörel yapı içerisinde oldukça düşük seviyelerde olup çalışan sayıları ve ücret seviyeleri ile ilişkilidir. Üretim değeri ve katma değerde, tüm sektörlerde ciddi anlamda eşitsizliklerin olduğu, sektör içi en büyük eşitsizlik seviyesinin ise imalat sektöründe yaşandığı belirlenmiştir. Ayrıca sektör içi Gini katsayıları korelasyon analizi yapılarak, çalışmada kullanılan göstergeler arası ilişkiler tespit edilmiştir.

\section{Sektörel Farklılıklar}

Sektörler arasındaki dengesizlikler refah seviyesinin gelişimini azaltarak ekonomileri olumsuz yönde etkiler. 1970 ve 1980'li yıllarda yaşanan ekonomik krizlerin kaynağı olarak sektörler arasındaki büyük ekonomik farklılıklar gösterilmektedir (Blais vd., 1990). Gelir dağılımındaki dengesizliklerden biri olarak kabul edilen sektörel ve sektörler arası eşitsizlikler üzerine yapılan çalışmalar, farklılıkların sebepleri ve eşitsizlik seviyelerinin belirlenmesine yöneliktir. Bu çalışmalarda sektörel farklılıklar genellikle sektörel kaymalar, istihdamla ilişkili faktörler, teknolojik gelişmeler, küreselleşme ve siyasi politikalar gibi faktörler ile incelenmektedir.

\subsection{Sektörel Kaymalar}

Ekonomik eşitsizlikleri tetikleyen sektörel kaymalar ile ilgili ilk araştırmaların, tarım ve sanayi sektörlerinin incelenmesi ile başladığı görülmektedir. Bu araştırmaların temelini oluşturan görüşler Simon Kuznets'e dayanmaktadır. Kuznets'in geliştirdiği büyüme ve gelir dengesizliği arasındaki ilişkiyi ortaya koyan Ters U Hipotezi’ne göre tarımdan sanayiye geçiş yapan ekonomilerde, tarım sektöründeki düşük ücretler sebebiyle kısa dönemde sektörel eşitsizlikler ortaya çıkacak, ancak uzun dönemde ekonomik büyüme ile birlikte gelir eşitsizliği azalacaktır (Kuznets, 1955: 26-28). İstihdam seviyeleri ve ücretler açısından sektörel farklılıkları işaret eden hipotez, sektörel farklılıklar konusunda öncü çalışma niteliğindedir. Benzer durumun sanayi sektöründen, hizmet sektörlerine geçiş sürecinde de yaşanacağını ifade eden Hoffmann ve Shi (2013), bunun sebebi olarak sektörel ücret farklılıklarını göstermektedir. Sektörel dönüşümlerin, fiziksel mal üretimi yapan firmaları da etkileyerek, imalatın ikinci plana atılacağını vurgulayan Vandermerwe ve Rada (1988: 314)'nın "servitizasyon” olarak isimlendirdiği süreç, firmaların hizmet üretimine 
yönelmelerine neden olmaktadır. Diğer taraftan sektörel kaymalar, sektörel nihai mal üretimlerini etkileyerek, sektörel üretimde ikame malların azalmasına yol açacaktır (Ngai \& Pissarides, 2007: 438). İkame mal üretiminin azalması, sektörel rekabeti olumsuz etkileyerek dengesizliklere neden olacaktır. Kısaca, ekonomilerin tarım - sanayi- hizmet dönüşümlerinde öne çıkan sektörler ve firmaların olması, sektörler arasında ve aynı sektörde faaliyet gösteren firmalar arasında farklılıkların oluşmasına yol açacaktır.

Diğer bir yaklaşıma göre, milli gelir seviyesindeki artış, sektörel eşitsizlikleri arttırmaktadır. $\mathrm{Bu}$ görüşe göre gelirdeki artış, tüketim yapısını etkileyen talebin, gelir esnekliği 1'den büyük mal ve hizmetlere yönelmesine yol açmaktadır. Bu yönelişi “Íhtiyaçlar Hiyerarşisi Teorisi” 'olarak ifade eden Schettkat ve Yocarini (2006)'ye göre gelir seviyesindeki artış, sektörel kaymalara neden olmaktır. Benzer şekilde kişi başı milli gelir düzeyinin sektörel yapıyı etkilediğini vurgulayan Summers (1985: 27), ülkelerin kişi başı milli gelir düzeyleri ile ülkelerin birincil sektörlerinin milli gelirden aldıkları paylar arasında anlamlı ilişki olduğunu belirlemiştir. Sektörel gelir farklılıklarının oluşmasına ve sektörel kaymalara sebep olan bu durum, sektörler arasındaki eşitsizlikleri arttırmaktadır.

\section{2. İstihdamla İlgili Faktörler}

İstihdamla ilişkili olan emek hareketliliği, ücretler ve kayıt dışı istihdam gibi faktörler, sektörel farklılıkları etkileyen unsurlar arasında yer almaktadır. Ters U hipotezine göre emek hareketliliği, yüksek ücretlerin olduğu sektörlere doğru olmaktadır (Kuznets, 1955: 2). Bu nedenle emek hareketliliği ve ücret farklılıkları birbiriyle yakın ilişkili kavramlardır. Avantajlarının yanı sıra kaybettirdikleri de olan emek hareketliliğinin başlıca nedeni olarak, sektörler arasındaki ücret farklılıkları görülmektedir (Stephenson \& Hufbauer, 2011: 278). Yüksek ücretlerin olduğu sektörlerde kalifiye işçi talebinin de yüksek olduğunu vurgulayan Van-Reenen (2011)'e göre, ücretlerdeki artışın temel sebebi bu talep artışıdır. Yüksek ücretler nedeniyle sektörlerde çalışan kalifiye işçilerin artması, üretim değerleri ve çalışan sayısı gibi değişkenleri etkileyerek, uzun dönemde de sektörler arasındaki eşitsizliklerin artmasına sebep olacaktır (Deininger \& Squire, 1998: 275). İşü̈cü hareketliliğini arttıran ücret dengesizlikleri, sektörel üretim değerleri ve sektörel büyüme düzeyleri arasında ciddi farklılıklar oluşturmaktadır. Ayrıca istihdam yoğunluğu yaşanan sektörlerde, diğer sektörlere nazaran görülen emek verimliliği artış1, sektörel büyümeyi ve dolayısıyla ekonomik büyümeyi etkilemektedir (Uppenberg, 2011: 20). Başka bir deyişle, ücretlerdeki artış, istihdam seviyelerinde, emek verimliliklerinde ve üretim çıktılarında artışa sebep olarak, sektörler arası büyüme oranlarında farklılıklar oluşturmaktadır. Dickens ve Katz (1986), işçi ücretlerinin sektörler arasındaki farklılıklara etkisini \%6,7 olarak hesaplamıştır.

Vergilendirilmeden ve yasal düzenlemelerden kaçınılarak gerçekleştirilen faaliyetler olarak tanımlanan kayıt dışı istihdam (Angel \& Tanabe, 2012: 5), sektörel farklılıkları etkileyen unsurlar arasındadır. Kayıt dışı faaliyetlerde çalışanlar, yeterli çalışma standartlarına sahip olmadan, asgari yaş haddi, asgari ücret hakkı, fazla mesai ücreti ve işyeri çalışma standartları gibi konularda düzenlemelere uyulmadan, sosyal güvenlik ve vergi gibi unsurların eksik ödendiği veya hiç ödenmediği durumlarla karşı karşıyadırlar (Ilgın, 1995: 
39). Bu açıdan kayıt dışı faaliyet gösteren firmalar, kayıtlı olan firmaların sorumluluklarını yerine getirmeyecekleri için, bu sorumlulukların getireceği maliyetlerden kurtulacaklardır. $\mathrm{Bu}$ çerçevede maliyetleri daha düşük olan kayıt dış1 firmalar ve kayıtdış1 istihdam düzeyi yüksek olan sektörler daha avantajlı olacaktır. Böylece kayıtdışı istihdam hem sektör içi hem de sektörler arası eşitsizliklerin artmasına neden olacaktır.

\subsection{Teknolojik Gelişmeler}

Teknolojik gelişmeler sosyal ve ekonomik yapıyı etkileyen dönüşümler ortaya çıkarırlar. Toffler (1980: 14)'a göre bilinçli tarıma geçiş, sanayileşme ve bilgi ekonomisine geçiş olmak üzere insanlığı etkileyen üç dönüşüm söz konusudur. Tarımsal ekonomide pulluk, sanayi ekonomisinde buhar makinası ve bilgi ekonomisinde de bilişim, dönemlerinin teknolojik gelişmeleri olarak odak noktası olmuşlar ve ekonomik yapıda dönüşümler ortaya çıkarmışlardır. Teknolojik gelişmeler kişisel, ulusal ve küresel boyutta sosyal, ekonomik ve politik etkileşimleri arttırmaktadır (Melnikas, 2011: 367). Teknolojik değişimlere ayak uyduran sektörlerde verimlilik, rekabet avantajı, süreç kontrolleri, karlılık, örgütsel esneklik, piyasa değerindeki artışların yanı sıra maliyetlerin, kalite farklılıklarının azalması gibi etkiler görülmektedir (Love vd., 2005: 947; Moriones \& Lopez, 2007: 362).

Günümüzde bilgi ekonomisi olarak ifade edilen sürecin bilgi ve iletişim (bilişim) teknolojileri olmak üzere iki unsuru vardır (Gürdal, 2004: 52). Organizasyonların özelliklerini ve fonksiyonlarını etkileyen stratejik bir araç olarak görülen bilişim sistemleri (Currie, 1996: 51), faaliyetleri şekillendiren faktörleri etkileyerek sektörel yapı üzerinde değişikliklere sebep olmaktadır (Porter \& Millar, 1985: 149). Sektörlerin ve firmaların sahip oldukları bilişim alt yapıları, hem sektör içi hem de sektörler arası etkileşimleri arttırmaktadır. Bu etkileşimler, bilişim sistemleriyle yakından ilişkili bir kavram olan ağ dışsallıkları sebebiyle, bilişim sistemlerine uyumu zorunlu hale getirmektedir. Bilişim sistemlerinin iş süreçlerinde organizasyonel ve sektörel verimliliği yükseltmesinin yanı sıra, kullananlar-kullanmayanlar arasında oluşturduğu eşitsizlikler sebebiyle sektörel dengesizliklere yol açmaktadır. Bazı araştırmalara göre sektörler arası eşitsizliklerin yoğun olarak çalışan ücretlerinde görüldüğü vurgulanmaktadır. Autor vd., bilgisayarlaşmanın, eğitim seviyelerinden kaynaklanan gelir eşitsizliği üzerindeki etkilerini incelemiştir. Çalışmada imalat ve imalat dışı sektörlerde, teknolojik açıdan vasıflı işçi sayılarının arttığı, bu artışın bilgisayar ile ilişkili sektörlerde daha yoğun olduğu belirlenmiştir (Autor vd., 1998). Bir başka çalışmada teknolojik değişimin bazı sektörlerde yaygın olduğu ve teknolojiyle birlikte nispi gelir artışının gözlenmesine rağmen, yüksek ücret alan vasıflı işçi oranlarının arttığı belirtilmektedir (Berman vd., 1998). Acemoglu'na göre ise teknolojik ilerlemelerin tetiklediği vasıflı işçi talebindeki artış teknoloji odaklı piyasaların genişlemesine yol açacaktır. Bu genişlemeyle birlikte kısa dönemde vasıflı işçilere ödenen primler azalsa dahi, uzun vadede artacaktır (Acemoglu, 1998). Bu çalışmalar, teknolojik ilerlemelere bağlı olarak artan ücret eşitsizliklerinin, ilerleyen süreçlerde de karşılaşılacak önemli sorunlar arasında olacağını ortaya koymaktadır. 


\subsection{Küreselleşme}

Heckscher - Ohlin modelinde, dış ticaret sonrası ülkeler arasında üretim faktörlerinin birbirine eşitleneceği vurgulanmaktadır. "Uluslararası faktör fiyatları eşitliği” olarak adlandırılan teoremde, serbest dış ticaret yapan ülkeler arasında göreceli ve mutlak faktör fiyatlarının birbirine eşitleneceği belirtilmektedir (Samuelson, 1948). Bu durumu emek piyasasında inceleyen Thewissen vd.'ne göre faktör fiyatlarının eşitlenmesi çerçevesinde, gelişmiş ülkelerdeki vasıfsız işçi ücretleri ile gelişmemiş veya gelişmekte olan ülkelerdeki vasıfsız işçi ücretleri eşitlenecektir. Sonuçta gelişmiş ülkelerde vasıflı işçilerin çalıştığı sektörler ile vasıfsız işçilerin çalıştığı sektörler arasında ücret eşitsizlikleri oluşacaktır. (Thewissen vd., 2013). Ülkelerdeki sektörel farklılıkların ortaya çıkmasını küreselleşmeye bağlayan görüşe göre, uluslararası ticaret ile talebi artan malların üretildiği sektörlerde işçi talebi ve çalışanlara verilen ücretler artar (Freeman, 1995: 15-16). Küreselleşme ile artan diş ticaretin sektörel farklılıklara sebep olduğunu vurgulayan Mahler (2004), ithalat ve ihracatın farklı etkiler ortaya çıkardığını vurgulamıştır. Bir ülkede ithalatın artması, o ülkedeki işçileri, yabancı işçiler ile rekabete iteceği için, istihdam ve ücret yapısına zarar vererek, ücretlerin azalmasına neden olacaktır. İhracatın artmasında ise bu durumun tersi söz konusu olup ihracatı artan ülkenin ücretlerinde artış gözlenecektir (Mahler, 2004: 1049). Ayrıca uluslararası ticaret sayesinde elde edilen gelirler belirli gruplarda toplanacak, dağılacak gelir miktarının azalması, eşitsizliklerin artmasına neden olacaktır (Van-Vliet, 2011; Winner, 2012: 38-39). Küreselleşmenin gelir eşitsizliklerini arttırdığını vurgulayan Dreher ve Gaston (2008)'a göre küreselleşme ile dış ticaretin yanı sıra, finansal hareketlerin de sektörel eşitsizlikler üzerine etkileri bulunmaktadır. Gelişmiş ülkelerin ekonomik politikalarından kaynaklanan gelir eşitsizlikleri, küreselleşme ile tüm ülkeleri olumsuz etkilemektedir. Küresel bir sorun olan eşitsizliklere gelişmiş ülkeler neden olmakta ve en fazla olumsuz etkileri gelişmiş ülkeler yaşamaktadır (Dreher \& Gaston, 2008:531).

\subsection{Siyasi Politikalar}

Siyasi iktidarların almış olduğu ekonomik kararlar, sektörel eşitsizlikler ile doğrudan ilişkilidir. Siyasi veya ülke öncelikleri sebebiyle, bazı sektörlere teşviklerin artırılması, yeni vergilerin getirilmesi, kamusal alanlarda yeni fiyatlandırma politikaları ve kamu yatırımlarının bölgesel farklılıkları, sektörler arasında üretim değerleri ve maliyetler açısından eşitsizlikler oluşturmaktadır (Karluk, 2005: 69). Ayrıca yanlış ekonomik politikalar sonucu ortaya çıkan yüksek enflasyon ve faiz oranları, sektörel yatırımları etkilemekte ve eşitsizlikleri arttırmaktadır. Siyasi karar alıcıların, alt gelir gruplarının desteklenmesi şeklinde politikalar geliştirmeleri, eşitsizliklerin azaltılmasında etkili olacaktır. Ancak eşitsizliğe kalıcı olarak çözüm getirilmesi, ücretler ve sermaye gelirleri arasındaki farkın azaltılmasına bağlıdır (OECD, 2008). Bu ise kişiler ve girişimler arasında fırsat eşitliğini tesis edecek, sektörel farklılıkları azaltıcı politikaların geliştirilmesi ile ilişkilidir. 


\section{Türkiye'de Sektörel Yapı}

Gerçekleştirilen ekonomik faaliyetlere göre şekillenen sektörel yapı, gelişmiş ve gelişmekte olan ülkelerde hizmet sektörüne yoğunlaşmaktadır. Yirmi birinci yüzyıl ortalarından itibaren birçok ülke hizmet sektörüne yönelmiştir. Sektörel yapıyı şekillendiren faktörler, tüm dünya ekonomilerini etkilediği gibi Türkiye ekonomisinde de yapısal değişimlerin ortaya çıkmasına neden olmuştur. Türkiye'de 1960 öncesi dönemde birincil sektör olan tarım sektörü yerini sanayi ve hizmet sektörlerine bırakmıştır. Türkiye'deki sektörlerin, üretime göre hesaplanan GSYIH içindeki payları ve istihdam oranlarının gösterildiği Şekil 1'de, en yüksek payların hizmet sektöründe olduğu görülmektedir.

Şekil: 1

Sektör Payları

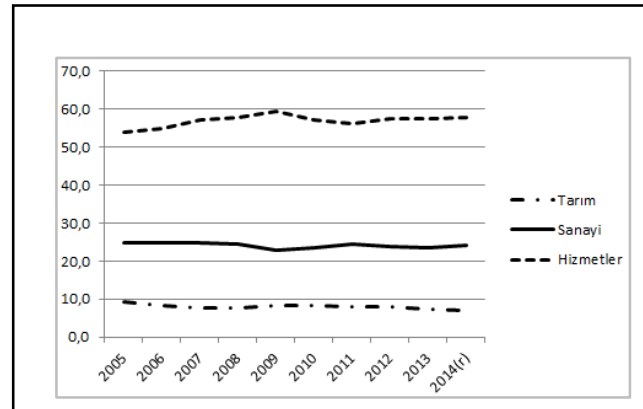

a)Sektörel GSYIH payları (\%)

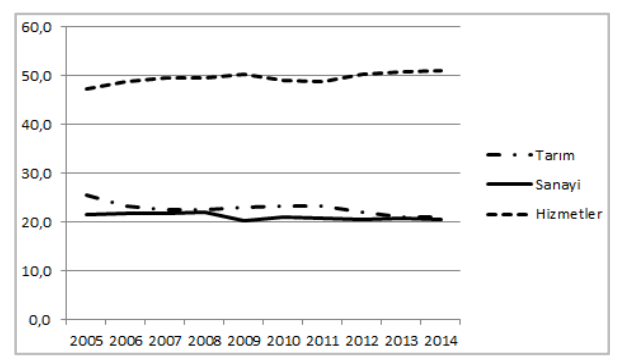

b)Sektörel istihdam payları (\%)

Kaynak: TÜIK Uluslararası seçilmiş göstergeler raporlarından derlenen veriler ile tarafimızdan hazırlanmıştır.

Tablo: 1

Nace Rev.2 Sektör Sinıflaması

\begin{tabular}{|c|l|}
\hline Sektör & \multicolumn{1}{|c|}{ Sektör Başlığı } \\
\hline C & İmalat \\
\hline D & Elektrik, gaz, buhar ve havalandırma sistemi üretim ve dağıtımı faaliyetleri \\
\hline E & Su temini, kanalizasyon, atık yönetimi ve iyileştirme faaliyetleri \\
\hline F & İnşaat \\
\hline G & Toptan ve perakende ticaret; Motorlu kara taşııtlarının ve motosikletlerin onarımı \\
\hline H & Ulaştırma ve depolama \\
\hline I & Konaklama ve yiyecek hizmeti faaliyetleri \\
\hline J & Bilgi ve iletişim \\
\hline L & Gayrimenkul faaliyetleri \\
\hline M & Mesleki, bilimsel ve teknik faaliyetler \\
\hline N & İdari ve destek hizmet faaliyetleri \\
\hline S & Diğer hizmet faaliyetleri \\
\hline
\end{tabular}

Kaynak: Eurostat, 2008: 57.

Avrupa Birliği İstatistik Ofisi (Eurostat) tarafından ekonomik faaliyetlerin sınıflandırılması ve bir standart oluşturulması amacıyla, 1970 yılında geliştirilmeye başlanan NACE (Nomenclature of Economic Activities) sistemi, 1990 y1lından itibaren kullanılmaya başlanmıştır. Birkaç ufak değişiklikle farklı versiyonları oluşturulan Nace, 2008 yılında en 
büyük değişikliğini yaşamış ve Nace Rev.2 ekonomik faaliyetleri sınıflama sistemi Avrupa Birliği sektörel araştırmalarında standart haline gelmiştir. Söz konusu sınıflama sistemi ile ekonomik faaliyet alanlarının belirlenmesine uluslararası boyut kazandırmak ve ülkeler arası karşılaştırmaları sağlamak amacı güdülmektedir (Eurostat, 2008: 13-14). Türkiye’deki sektörel araştırmalarda Nace Rev.2 sisteminin kullanılmasına 2010 yılı itibariyle başlanmıştır. Girişimler ile ilgili araştırma raporlarında yer alan Nace Rev.2 sektörleri Tablo 1 'de sunulmaktadir.

\section{Tablo: 2}

Sektörel Göstergeler

\begin{tabular}{|c|c|c|c|c|c|c|c|c|c|}
\hline Sektör & & Girişim Sayısı & Bilgisayar & İnternet & Web Sahipliği & Çalışan Kişi & Ödenen Ücretler & Üretim Değeri & Katma Değer \\
\hline \multirow[t]{4}{*}{$\mathrm{C}$} & $10-49$ & 330160 & 288479 & 281407 & 165998 & 1506680 & 17031400 & 187460 & 32412 \\
\hline & $50-249$ & 8598 & 8434 & 8433 & 6223 & 891848 & 17297081 & 206005838 & 40188054 \\
\hline & $250+$ & 1680 & 3505 & 3505 & 3293 & 1132449 & 35722110 & 460672292 & 89984796 \\
\hline & Toplam & 340438 & 300419 & 293346 & 175514 & 3530977 & 70050591 & 666865591 & 130205262 \\
\hline \multirow[t]{4}{*}{ D-E } & $10-49$ & 4330 & 4085 & 3931 & 2303 & 0 & 0 & 51958 & 0 \\
\hline & $50-249$ & 246 & 239 & 239 & 181 & 17295 & 683544 & 34907 & 3049922 \\
\hline & $250+$ & 128 & 127 & 127 & 102 & 126905 & 4882245 & 71711 & 19199626 \\
\hline & Toplam & 4704 & 4452 & 4297 & 2586 & 144200 & 5565789 & 158576 & 22249547 \\
\hline \multirow[t]{4}{*}{$\mathrm{F}$} & $10-49$ & 153420 & 138327 & 136405 & 70088 & 776773 & 7741960 & 115417 & 15637481 \\
\hline & $50-249$ & 3786 & 3673 & 3648 & 2417 & 363233 & 5102534 & 62679 & 8773 \\
\hline & $250+$ & 452 & 446 & 444 & 380 & 208123 & 4412355 & 42819 & 8352 \\
\hline & Toplam & 157658 & 142446 & 140497 & 72885 & 1348129 & 17256850 & 220916 & 15654606 \\
\hline \multirow[t]{4}{*}{$\mathrm{G}$} & $10-49$ & 1070639 & 1028717 & 1020899 & 569302 & 2418722 & 20601877 & 111633 & 48720 \\
\hline & $50-249$ & 3463 & 3406 & 3406 & 2596 & 319681 & 7389891 & 43195 & 17933 \\
\hline & $250+$ & 469 & 468 & 468 & 415 & 433980 & 12022062 & 57139 & 25985 \\
\hline & Toplam & 1074571 & 1032592 & 1024774 & 572312 & $\mathbf{3 1 7 2 3 8 3}$ & 40013830 & 211967 & 92639 \\
\hline \multirow[t]{4}{*}{$\mathrm{H}$} & $10-49$ & 420472 & 375769 & 373418 & 173413 & 740353 & 4790479 & 78489 & 11414 \\
\hline & $50-249$ & 1096 & 1061 & 1032 & 594 & 106652 & 2257978 & 22416 & 4725 \\
\hline & $250+$ & 202 & 202 & 202 & 179 & 248270 & 11050285 & 63329 & 20228 \\
\hline & Toplam & 421770 & 377032 & 374651 & 174186 & 1095275 & 18098741 & 164234 & 36368 \\
\hline \multirow[t]{4}{*}{ I } & $10-49$ & 230886 & 190291 & 186741 & 114986 & 582376 & 4536160 & 26310 & 6424 \\
\hline & 50-249 & 1547 & 1495 & 1495 & 1176 & 160104 & 0 & 0 & 0 \\
\hline & $250+$ & 305 & 304 & 304 & 300 & 202025 & 4107774 & 20525 & 7592 \\
\hline & Toplam & 232738 & 192089 & 188540 & 116462 & 944505 & 8643934 & 46836 & 14015 \\
\hline \multirow[t]{4}{*}{$\mathrm{J}$} & $10-49$ & 31412 & 30857 & 30511 & 24003 & 88567 & 1638429 & 12649 & 3038 \\
\hline & 50-249 & 305 & 297 & 293 & 258 & 30960 & 0 & 0 & 0 \\
\hline & $250+$ & 67 & 67 & 67 & 61 & 67538 & 4162135 & 38599 & 14032 \\
\hline & Toplam & 31784 & 31222 & 30871 & 24322 & 187065 & 5800564 & 51248 & 17070 \\
\hline \multirow[t]{4}{*}{$\mathrm{M}$} & $10-49$ & 153909 & 141657 & 138387 & 85392 & 415540 & 5293582 & 36475 & 14512 \\
\hline & $50-249$ & 462 & 460 & 460 & 316 & 46300 & 2057100 & 12377 & 3733 \\
\hline & $250+$ & 84 & 81 & 80 & 61 & 46688 & 1470953 & 5465 & 2446 \\
\hline & Toplam & 154455 & 142198 & 138928 & 85770 & 508528 & 8821635 & 54316 & 20690 \\
\hline \multirow[t]{4}{*}{$\mathrm{N}$} & $10-49$ & 26199 & 22318 & 21897 & 10897 & 138327 & 1734497 & 21841 & 3558 \\
\hline & 50-249 & 2053 & 1922 & 1871 & 923 & 233315 & 3418739 & 15658 & 5188 \\
\hline & $250+$ & 773 & 753 & 750 & 424 & 631162 & 10081979 & 21646 & 12968 \\
\hline & Toplam & 29025 & 24992 & 24519 & 12244 & 1002804 & 15235215 & 59145 & 21714 \\
\hline \multirow[t]{4}{*}{$S$} & $10-49$ & 154114 & 148785 & 148785 & 114287 & 234678 & 1041724 & 4700 & 1434 \\
\hline & $50-249$ & 79 & 79 & 79 & 50 & 6803 & 106387 & 0 & 162 \\
\hline & $250+$ & 6 & 6 & 6 & 5 & 2570 & 68364 & 241 & 87 \\
\hline & \begin{tabular}{|l|} 
Toplam \\
\end{tabular} & 154199 & 148870 & 148870 & 114342 & 244051 & 1216475 & 4940 & 1683 \\
\hline \multicolumn{2}{|c|}{ Genel Toplam } & 2601342 & 2396312 & 2369292 & 1350624 & 12177917 & 190703624 & 667837769 & 168313596 \\
\hline
\end{tabular}

Kaynak: TÜIK 2013 yılı "Girişimlerde Bilişim Teknolojileri Kullanım Araştırma" raporları ve "Ekonomik Faaliyetler ve Büyüklük Gruplarına Göre Girişim İstatistikleri” raporlarından derlenerek hazırlanmış̧tır.

Tablo 1'de yer alan sektörler temel alınarak hazırlanan Tablo 2'de, Türkiye'deki girişimler ile ilgili girişim sayısı, bilgisayar kullanımı, internet kullanımı, web sayfa sahipliği, çalışan kişi sayısı, ödenen ücretler, üretim değeri ve faktör maliyetlerine göre katma değerlerin sektörel dağılımları, çalışan sayılarına göre gruplandırılarak gösterilmektedir. Tablo 2, TÜİK’in yayınladığı 2013 yılına ait "Girişimlerde Bilişim 
Teknolojileri Kullanım Araştırması" raporlarına uygun olarak düzenlenmiştir. Girişim sayılarına dair 2014 ve 2015 verileri TÜIKK raporlarında yer almadığı için, çalışmada 2013 verileri kullanılmıştır. Söz konusu raporlarda D ve E sektörleri beraber değerlendirildiğinden dolayı, tabloda D-E şeklinde düzenlenmiştir. Ayrıca TÜİK raporlarında yer almayan verilerin, toplamlar üzerinde etkisinin bulunmadığ 1 varsayılarak, bu göstergelere ait veriler sıfır kabul edilmiştir. Eksik verilerin L sektöründe fazla olması nedeniyle, bu sektöre analizde yer verilmemiştir.

Türkiye'de 2013 yılında sektörel yapıyla ilgili girişim sayıları, bilgisayar kullanımı, internet kullanımı ve web sayfası sahipliği verilerinin yanı sıra, sahip oldukları çalışan sayısı, çalışanlara ödenen ücret, üretim değerleri ve faktör maliyetine göre katma değer seviyeleri verilmektedir. Tabloya göre en fazla girişim sayısının ulaştırma ve depolama $(\mathrm{H})$, ikinci sırada imalat (C) sektöründe, en az ise D-E sektöründe olduğu görülmektedir. İstihdam açısından bakıldığında sahip olunan çalışan sayısına göre ilk sırada C, ikinci sırada $\mathrm{G}$ sektörü gelmektedir. En fazla çalışan sayısına sahip olan $\mathrm{C}$ sektörü toplam ödenen ücretler, üretim değeri ve katma değer açısından en yüksek seviyelere sahiptir. Bilgisayar tamiri gibi teknik hizmetleri içeren S sektörü toplam ücret ödemelerinin, üretim değerinin ve katma değerin en düşük seviyede gerçekleştiği sektördür. En az katma değer üretilen ikinci sektör ise konaklama ve yiyecek hizmetleri (I) sektörüdür.

\section{Eşitsizlikler ve Ölçülmesi}

Kaynakların sınırlı olduğu ilkesi üzerine inşa edilen iktisadi anlayışa göre dağılımda yaşanan farklılıklar sistemde dengesizliklere sebep olur. Farklılıkları vurgulamak amacıyla kullanılan matematiksel bir terim olan eşitsizlik kavramı, dağılımlardan birinin diğerine göre farklılık gösterdiği durum olarak tanımlanmaktadır (Karoly, 1992: 107). Eşitsizlik ölçüleri bu farklılıkların karşılaştırılmasında kullanılan bir araç niteliğindedir. Kaynakların insanlar arasında eşit olmayan bir şekilde paylaşılması, refah seviyelerinin farklı olmasına ve dolayısıyla toplam refahta azalmaya neden olur. Bu bağlamda sosyoekonomik eşitsizliklerin ölçülmesi ve farklılık düzeylerinin belirlenmesi, sorunun çözümü açısından önem arz etmektedir. Eşitsizlik derecesinin ölçülmesi, söz konusu farklılık seviyelerinin ortaya konulması amacıyla, yüzdelik dilimler, varyans katsayısı, Gini indeksi, Theil indeksi gibi farklı istatistiksel yöntemler kullanılarak gerçekleştirilmektedir (Atkinson, 1970; Karoly, 1992; Cowell \& Jenkins, 1995; Shankar \& Shah, 2003; Chakraborty \& Bosman, 2005). Birçok ölçüm aracının olmasına karşın eşitsizliklerin ölçülmesinde kullanılacak en iyi yöntem Gini katsayıları olarak görülmektedir (Maclachlan \& Sawada, 1997: 380; Chakraborty \& Bosman, 2005: 396).

\subsection{Gini Katsayıları}

İtalyan istatistikçi olan Corrado Gini tarafından 1912 yılında geliştirilen bu yöntem, farklı gelir dağılımlarının oluşturduğu eşitsizliği sayısal olarak ifade edebilme imkanı vermektedir (Ceriani \& Verme, 2012: 421-422). Gini katsayısı, gelir eşitsizliğinin grafiksel olarak gösterimi olan ve Max Otto Lorenz tarafından 1905 yılında geliştirilen Lorenz eğrisi temel alınarak elde edilmektedir. Lorenz eğrisi, üretilen toplam gelirden kişilerin ne oranda 
pay aldıklarının grafiksel gösterimidir (Kakwani, 1977: 719). Nüfus, belirlenen gelir seviyelerine göre bölümlere ayrılır ve her bir kesimin gelirleri kümülatif olarak tespit edilir (Chakraborty \& Bosman, 2005: 398-400). Nüfus içerisindeki gelir dağılımı eşitsizliklerini gösteren Lorenz eğrisi Şekil 2' de görülmektedir. Eşitsizlik, mutlak eşitlik doğrusu olarak isimlendirilen köşegen ile Lorenz eğrisi arasındaki A alanı ile belirlenmektedir. A alanının büyük olması dağılımdaki eşitsizliğin fazla olduğunu, küçük olması eşitsizliğin düşük seviyede olduğunu göstermektedir. Diğer taraftan toplam gelirin tek bir kesimde veya kişide toplandığ 1 tam eşitsizlik durumunda, Lorenz eğrisi köşegenlerden oluşacak ve A alanı, dik üçgenin alanına eşit olacaktır (Maclachlan \& Sawada, 1997: 380).

Şekil: 2

\section{Lorenz Ĕgrisi}

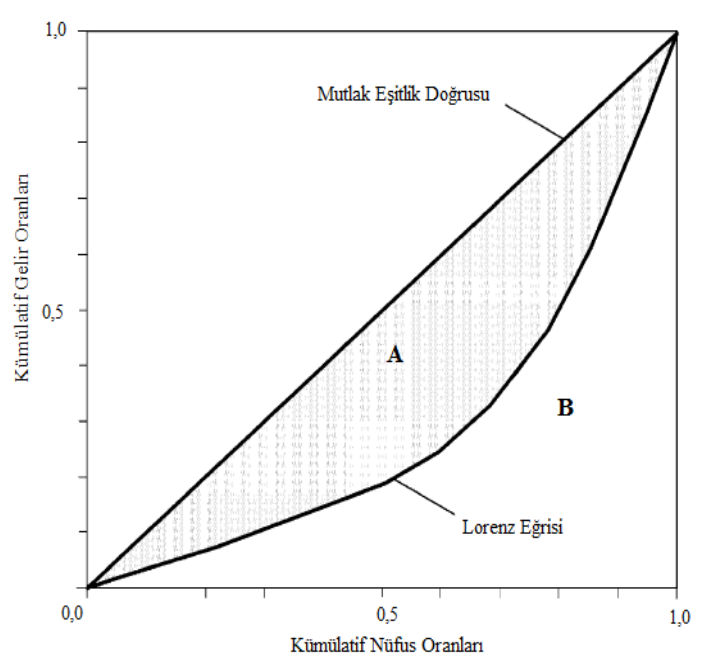

Lorenz eğrisi eşitsizliklerin grafiksel olarak değerlendirilmesinde güçlü bir araç olmasına karşın, eşitsizliklerin karşılaştırılması ve yorumlanması noktasında yetersiz kalmaktadır. Bu yetersizlik Lorenz eğrisiyle oluşan alanların oranlanması ile aşılabilir. A alanın, üçgen içerisindeki payı, eşitsizliğin sayısal büyüklüğünü verir. Eşitsizlik seviyelerinin sayısal olarak hesaplanması, eşitsizliğin büyüklügü ile ilgili daha net karar verilebilmesini sağlayacaktır.

Eşitsizliklerin sayısal ifade edilebilmesi amacıyla kullanılan indekslerden olan Gini yaklaşımı, farklılıkların toplamını temel alan bir yöntemdir (Goodman \& Kruskal, 1959: 123). Sosyoloji, ekonomi, coğrafya, biyoloji gibi alanların yanı sıra sağlık, endüstriyel yerleşim, eğitim gibi çalışma alanlarında, dağılım farklılığının sayısal seviyelerini belirlemek amacıyla kullanılmaktadır. Gini yoğunlaşma oranı veya Gini indeksi olarak da isimlendirilen Gini katsayısı, eşitsizliklerin ölçülmesinde kullanılan en uygun yöntemdir (Chakraborty \& Bosman, 2005:396). Şekil 2'de verilen Lorenz eğrisi ile mutlak eşitlik 
doğrusu arasındaki alanın (A), mutlak eşitlik doğrusu altında yer alan dik üçgene $(A+B)$ oranı Gini katsayısı olarak isimlendirilir ve (1) nolu denklem ile elde edilir.

$$
\begin{aligned}
& G=\frac{A}{A+B} \\
& G=\frac{1}{n}\left(n+1-2 \frac{\sum_{i=1}^{n}(n+1-i) y_{i}}{\sum_{i=1}^{n} y_{i}}\right) \\
& G=\sum_{i=1}^{n}\left|X_{i} Y_{i+1}-X_{i+1} Y_{i}\right|
\end{aligned}
$$

Gini katsayısı, Lorenz eğrisindeki alanlar kullanılmadan (2) nolu denklem ile hesaplanabilir. Denklemde $n$ tane grubun her biri $i$ ile ifade edilmekte, $Y_{i}$ gelirin birikimli yüzdesini göstermektedir (Shankar \& Shah, 2003). Gini değerinin, nüfus bilgisine yer verilmeden hesaplandığı denklem, nüfusun eşit dağılımda olduğu varsayımı altında kullanılabilir. Ancak farklı nüfus büyüklüklerine sahip bölgelerin analizinde hesaplamaların nüfusa göre ağırlıklandırılması daha sağlıklı sonuçlar ortaya çıkaracaktır. Bu durumda Gini katsayılarının hesaplanmasında (3) nolu denklem kullanılmalıdır. Denklemde $n$ bölge sayısını, $X_{i}$ i'nci bölge kümülatif nüfus oranını, $Y_{i}$ i'nci bölge kümülatif gelir oranını göstermektedir. Söz konusu denklem kullanılarak yapılacak hesaplama öncesi, gelir gruplarının küçükten büyüğe doğru sıralanmasının gerektiği vurgulanmaktadır (Maclachlan \& Sawada, 1997). Oran sonucu oluşan $\mathrm{G}$ değeri 0 ile 1 arasındadır. A alanı büyürse (Lorenz eğrisinin mutlak eşitlik doğrusundan uzaklaşma durumu) G değeri 1'e yaklaşır ve bu durum eşitsizliğin arttığı anlamına gelir. A alanı küçülürse (Lorenz eğrisinin mutlak eşitlik doğrusuna yaklaşma durumu) $\mathrm{G}$ değeri 0’a yaklaşır ve eşitsizlik azalır.

\subsection{Türkiye'de Sektörel Eşitsizlikler Üzerine Yapılan Çalışmalar}

Eşitsizlik ölçümleri sosyal ve ekonomik araştırmalarda yaygın olarak kullanılmaktadır. Özellikle literatürde, nüfus ve gelir dağılımları arasındaki eşitsizlik seviyelerinin belirlenmesine yoğunlaşıldığı, analizlerin demografik değişkenler çerçevesinde kişisel, bölgesel ve küresel düzeyde gerçekleştirildiği görülmektedir. Türkiye'de eşitsizlikler ile ilgili ilk çalışmalar 1933 yılında kişiler arasında gelir eşitsizliklerinin belirlenmesi amacıyla yapılmıştır (Karluk, 2005: 77). Araştırmalar genellikle kişisel ve bölgesel gelir dengesizliklerle ilgili olup, firmalar ve sektörler arasındaki farklılıkların belirlenmesi üzerine fazla yoğunlaşılmamıştır. Gerçekleştirilen sektörel analizlerin ise sektörlerin tarım, sanayi ve hizmet şeklinde genelleştirilerek veya sadece belirli bir sektör çerçevesinde yapıldığı görülmektedir.

Türkiye'de sektörel farklılıkların, bölgesel eşitsizlikler üzerindeki etkisinin araştırıldığı bir çalışmada, Gini indeksi ile bölgesel eşitsizliklerin sanayi sektöründe en yüksek seviyede olduğu ancak bölgesel eşitsizliklerin kaynağı olarak hizmet sektörü olduğu tespit edilmiştir (Öztürk, 2012). Gelir farklılıklarının bölgesel analizini gerçekleştiren Filiztekin ve Çelik (2010)'e göre, tarım sektörünün gelir eşitsizliğinde önemli bir payı bulunmaktadır. Bunun sebebi ise tarımsal gelirlerin azalmasına karşın istihdam düzeyinin azalmamasıdır. Tarım sektöründe yapılan kamu desteklerinin dağılımda eşitsizliklere neden 
olduğunu vurgulayan Öztürk ve Aktar (2009), 2000-2007 yılları arasında Karadeniz Bölgesindeki illerde, tarımsal desteklemelerin eşit dağıtılmadığını Gini katsayılarıyla ortaya koymuşlardır. Söz konusu desteklemelerin, sektör içi eşitsizliklerin artmasına sebep olacağ1 vurgulanan çalışmada, kamu politikalarının yeniden gözden geçirilmesinin gerektiği belirtilmiştir (Öztürk \& Aktar, 2009).

Eşitsizliklere ücretler açısından yaklaşan araştırmalarda, ücret farklılıkları kamu-özel sektör karşılaştırması ile incelenmektedir. Özel sektör ve kamu sektöründeki ücret seviyelerini inceleyen Tansel (2005), kamu sektörü ücretlerinin özel sektöre nazaran daha yüksek olduğunu ve özel sektörde cinsiyetler açısından büyük bir ücret açığının bulunduğunu tespit etmiştir. Kamu ve özel sektör çalışanları arasında hem cinsiyet hem de yaş açısından demografik eşitsizliklerin yanı sıra, ücret eşitsizliklerinin olduğu tespit edilmiştir (Çelik \& Sevim, 2014). Taştan ve Akar (2013) ise Türkiye'de sektörler arası ücret eşitsizliklerinin arttığını, özellikle bu artışın kriz dönemlerinde daha fazla olduğunu belirlemişlerdir.

Kamu ve özel sektör farklılıklarının incelendiği çalışmaların yanı sıra belirli bir sektör veya sektörler arası eşitsizliklerin araştırıldığ 1 sayılı çalışma bulunmaktadır. Bu çalışmalarda sektörün diğer sektörler üzerindeki etkileri konu alınmaktadır. İmalat sektöründe ücret eşitsizliklerinin incelendiği bir çalışmada, Türkiye'nin doğu ve batısı arasında ciddi ücret farklılıkların olduğu belirlenmiştir (Elveren \& Galbraith, 2005). Turizm sektörünün diğer sektörlerle etkileşimini belirlemek amacıyla Yamak, Tanrı̈ver ve Güneysu (2012) tarafindan uzun dönemde turizm gelirlerinin ekonomiye hiçbir katkısının bulunmadığ 1 , üretim değerleri açısından diğer sektörlerle anlamlı ilişkisinin olmadığı ortaya koyulmuştur. Kısa dönemde ise turizm sektörünün, sanayi sektörünün gelişimine katkı sağladığ1 vurgulanmıştır (Yamak vd., 2012).

\section{Araştırma Bulguları}

Araştırma yöntemini oluşturan Gini katsayılarının hesaplanma şekli Tablo 3 'de sunulmuştur. Türkiye'deki bilgisayar kullanımında sektörler arasındaki sayısal bölünme düzeyini gösteren Gini değerinin hesaplandığı söz konusu tablo oluşturulurken, öncelikle Tablo 2'de verilen sektörel firma sayıları ve sektörlerdeki bilgisayar kullanan firma sayıları tespit edilmiştir. Tabloda her bir sektör $(i)$, her bir sektördeki bilgisayar kullanan girişim sayısının tüm sektörlerdeki bilgisayar kullanan girişim sayısına oranı $\left(y_{i}\right)$ ve her bir sektördeki girişim sayısının tüm sektörlerdeki girişim sayısına oranı $\left(x_{i}\right)$ ile gösterilmektedir. Örneklendirilecek olursa, inşaat sektöründe (F) girişim sayısı 157658 ve tüm sektörlerdeki toplam girişim sayısı 2601342'dir. Buna göre inşaat sektörü girişim sayısının, toplam girişimler içerisindeki payı $\left(x_{i}\right)$ 0,06 olarak hesaplanır. Aynı sektörde bilgisayar kullanan girişim sayısı 142446 ve tüm sektörlerde bilgisayar kullanan toplam girişim sayısı 2396312 dir. Buna göre $\left(y_{i}\right)$ değeri 0,059 olarak hesaplanır. Kümülatif değerlerin hesaplanmasından önce, diğer çalışmalarda gelir seviyelerine göre küçükten büyüğe doğru yapılan sıralama, bu çalışmada bilgisayar kullanan firma sayısına göre yapılmıştır. Gini değerini firma sayılarına göre ağırlıklandırmak için (3) nolu denklem kullanılmış ve hesaplama sonucunda Gini değeri 0,0212 bulunmuştur. 
Fidan, H. \& H. Şen (2017), “Türkiye'de Sektörel Eşitsizlikler ve

Sayısal Bölünme İlişkisi”, Sosyoekonomi, Vol. 25(32), 31-50.

Tablo: 3

Gini Katsayılarının Kesaplanması

\begin{tabular}{cccccc}
\hline Sektör & $\begin{array}{c}\text { Girişim } \\
\text { Oran1 }\left(x_{i}\right)\end{array}$ & $\begin{array}{c}\text { Bilgisayar Kullanım } \\
\text { Oranı }\left(y_{i}\right)\end{array}$ & $\begin{array}{c}\text { Kümülatif Girişim } \\
\text { Oranı }\left(X_{i}\right)\end{array}$ & $\begin{array}{c}\text { Kümülatif Bilgisayar } \\
\text { Kullanım oranı }\left(Y_{i}\right)\end{array}$ & $\left|X_{i} Y_{i+1}-X_{i+1} Y_{i}\right|$ \\
\hline D,E & 0,001808 & 0,001858 & 0,001808 & 0,001858 & 0,000002 \\
N & 0,011158 & 0,010430 & 0,012966 & 0,012287 & 0,000019 \\
J & 0,012218 & 0,013029 & 0,025184 & 0,025316 & 0,000009 \\
M & 0,059375 & 0,059340 & 0,084559 & 0,084657 & 0,000104 \\
F & 0,060606 & 0,059444 & 0,145166 & 0,144101 & 0,000477 \\
S & 0,059277 & 0,062125 & 0,204443 & 0,206225 & 0,002062 \\
I & 0,089468 & 0,080160 & 0,293911 & 0,286386 & 0,000633 \\
C & 0,130870 & 0,125367 & 0,424781 & 0,411753 & 0,000075 \\
H & 0,162136 & 0,157338 & 0,586917 & 0,569091 & 0,017825 \\
G & 0,413083 & 0,430909 & 1,000000 & 1,000000 & 0,000000 \\
\hline & \multicolumn{5}{c}{} \\
\hline
\end{tabular}

Tablo 3’te hesaplanan Gini değeri 2013 yılı itibariyle sektörler arasında, bilgisayar kullanan girişim sayıları açısından yüksek seviyede bir eşitsizliğin olmadığını göstermektedir. Bu sonuç tüm sektörlerdeki girişimlerin, faaliyet alanları, teknolojik alt yapıları ve sermaye birikimleri farklı olsa dahi, bilgisayar kullanımına yöneldiğini ifade etmektedir. Tablo 2'deki değerler, sektörler arasında büyük farklılıkların olduğu kanısı uyandırsa da, hesaplanan Gini değerinin 0'a çok yakın olması, sektörler arası bilgisayar kullanımlarının eşit dağılıma yakın olduğunu göstermektedir. Bu durum, bilgisayar kullanımında sektörler arası sayısal uçurumun bulunmadığı şeklinde ifade edilebilir. Tablo 3 'te verilen yöntem kullanılarak, Türkiye'deki girişimlerde internet kullanımları, web sayfa sahipliği, çalışan sayısı, ücretler, üretim değerleri ve faktör maliyetlerine göre katma değer göstergelerinin sektörler arası Gini değerleri hesaplanarak Tablo 4 'te sunulmuştur.

Tablo 4’teki Gini değerlerine bakıldığında en düşük Gini değerleri bilgisayar ve internet kullanımları ile web sayfası sahipliğindedir. Bu değerlere göre Türkiye'de sektörler arası en düşük eşitsizlikler bilişim sistemleri kullanımlarında görülmektedir. Bilgisayar ve internet kullanımlarındaki farklılıkların birbirine oldukça yakın olduğu tablodaki değerlere göre bilişim sistemleri arasında en yüksek Gini değeri web sayfası sahipliğindedir. $\mathrm{Bu}$ değere göre, web sayfası sahipliğinin daha yüksek sayısal bölünme seviyesine sahip olduğu söylenebilir. Sektörel faaliyetler ile ilgili olan çalışan sayısı, ücretler, üretim değeri ve katma değer göstergelerinde hesaplanan Gini değerleri, bilişim sistemleri kullanımlarından daha yüksektir. Çalışan sayılarına göre sektörler arasındaki eşitsizlik düzeyi 0,289 olarak hesaplanmıştır. Sektörler arası en yüksek eşitsizlik ise 0,8682 ile üretim değerlerinde yaşanmaktadır. Özellikle üretim değeri ve katma değer göstergelerinde hesaplanan Gini katsayıları, sektörler arasında ciddi bir eşitsizliğin olduğunu, değerlerin 1'e yakın olması tam eşitsizliğe yaklaşıldığını işaret etmektedir. Söz konusu eşitsizlik sektörler arası katma değer ve üretim değerlerindeki farklılıklardan kaynaklanmaktadır. Özellikle imalat ve inşaat sektörlerindeki katma değer ve üretim değerlerinin diğer sektörlere nazaran yüksek olması eşitsizliğin temel nedenidir. Diğer taraftan ulaştırma ve depolama, konaklama ve yiyecek hizmeti faaliyetleri, bilgi ve iletişim, gayrimenkul faaliyetleri, mesleki, bilimsel ve teknik faaliyetler gibi hizmet sektörlerinde katma değer ve üretim değerlerinin düşük düzeylerde olması, söz konusu eşitsizliğin artmasına yol açmaktadır. 
Tablo: 4

Bazı Göstergelere Ait Sektörlerarası Gini Değerleri

\begin{tabular}{lcc}
\hline & Göstergeler & Gini değeri \\
\hline Bilgisayar kullanımı & 0,0212 \\
İnternet kullanımı & 0,0241 \\
Web sayfa sahipliği & 0,0327 \\
Calışan sayıları & 0,2890 \\
Ücretler & 0,3700 \\
Üretim değeri & 0,8682 \\
Katma değer & 0,8322 \\
\hline
\end{tabular}

Sektör içi eşitsizlikleri gösteren Gini katsayılarının verildiği Tablo 5 'teki sektörler, girişimlerde çalışan kişi büyüklüklerine göre gruplandırılmıştır. Tüik tarafından çalışan sayılarına göre 10-49, 50-249 ve 250 üzeri olmak üzere girişimler üç gruba ayrılmıştır. Sektör içi eşitsizliklerin Gini ile hesaplanabilmesi için bu gruplarda yer alan girişimlere ait veriler temel alınmıştır.

\section{Tablo: 5}

Sektör İçi Gini Değerleri

\begin{tabular}{cccccccc}
\hline Sektör & $\begin{array}{c}\text { Bilgisayar } \\
\text { Kullanım }\end{array}$ & $\begin{array}{c}\text { İnternet } \\
\text { Kullanım }\end{array}$ & $\begin{array}{c}\text { Web Sayfa } \\
\text { Sahipliği }\end{array}$ & $\begin{array}{c}\text { Çalışan } \\
\text { Sayısı }\end{array}$ & Ücretler & $\begin{array}{c}\text { Üretim } \\
\text { Değeri }\end{array}$ & $\begin{array}{c}\text { Katma } \\
\text { Değer }\end{array}$ \\
\hline C & 0,009709 & 0,010668 & 0,024326 & 0,549960 & 0,738340 & 0,985451 & 0,985492 \\
D, E & 0,002789 & 0,005743 & 0,030009 & 0,963253 & 0,963025 & 0,610498 & 0,961890 \\
F & 0,002036 & 0,002246 & 0,011530 & 0,399868 & 0,529780 & 0,454511 & 0,025776 \\
G & 0,000093 & 0,000122 & 0,001602 & 0,234307 & 0,482360 & 0,470469 & 0,471241 \\
H & 0,000271 & 0,000215 & 0,001361 & 0,321513 & 0,733764 & 0,519949 & 0,684451 \\
I & 0,001406 & 0,001583 & 0,004718 & 0,376648 & 0,477398 & 0,440666 & 0,543416 \\
J & 0,000112 & 0,000169 & 0,001448 & 0,517956 & 0,718142 & 0,753442 & 0,821642 \\
M & 0,000274 & 0,000357 & 0,000863 & 0,179547 & 0,396769 & 0,325119 & 0,295350 \\
N & 0,009740 & 0,009680 & 0,013099 & 0,803018 & 0,829619 & 0,552195 & 0,774668 \\
S & 0,000020 & 0,000020 & 0,000075 & 0,037859 & 0,143128 & 0,049133 & 0,147458 \\
\hline
\end{tabular}

Tablo 5'te verilen Gini katsayıları genel olarak incelendiğinde, sektör içi en düşük eşitsizliklerin diğer hizmet faaliyetleri (S) ve en yüksek imalat (C) sektöründe olduğu görülmektedir. Sayısal bölünmeyi gösteren bilgisayar ve internet kullanımları ile web sayfası sahipliğindeki eşitsizlikler, sektörler arası eşitsizlik seviyesinde olduğu gibi, diğer göstergelere nazaran daha düşüktür. Tüm sektörlerde, bilişim sistemleri kullanımlarındaki sektör içi en yüksek sayısal bölünme yine web sayfası sahipliğindedir. Bilgisayar ile internet kullanımlarında en yüksek sayısal bölünme idari ve destek hizmet faaliyetleri (N) ve imalat (C) sektörlerinde iken, web sayfası sahipliğinde elektrik, gaz, buhar ve havalandırma sistemi üretim ve dağıtım faaliyetleri (D-E) sektöründedir. Sektörler arası Gini değerleri ile karşılaştırıldığında, sektör içi değerlerin daha düşük olduğu dikkat çekmektedir. Bilgisayar ve internet kullanımları ile web sayfası sahipliği sektör içi Gini değerlerinin aritmetik ortalaması sirasıly $0,00260,0030$ ve 0,0089 'dur. Bu değerler, sektörler arası sayısal bölünmenin, sektör içi sayısal bölünmeden daha fazla olduğunu göstermektedir.

Sektörel faaliyetlerle ile ilgili olan çalışan sayısı, ücretler, üretim değeri ve katma değer göstergelerindeki sektör içi eşitsizlikler, bilişim sistemleri kullanımlarına nazaran daha yüksektir. Çalışan sayısına göre, sektör içi gruplar arasındaki eşitsizliğin en yüksek 
olduğu sektör elektrik, gaz, buhar ve havalandırma sistemi üretim ve dağıtım faaliyetleri (DE), en düşük olduğu sektör ise mesleki, bilimsel ve teknik faaliyetler (M)'dir. Bu tespit, çalışan sayısı büyüklüğü açısından girişimlerin $M$ sektöründe daha dengeli olduğunu göstermektedir. Ücretler ile ilgili sektör içi eşitsizlikler en yüksek elektrik, gaz, buhar ve havalandırma sistemi üretim ve dağıtım faaliyetleri (D-E) ve idari ve destek hizmet faaliyetleri (N) sektörlerinde iken, diğer hizmet faaliyetleri (S) ve mesleki, bilimsel ve teknik faaliyetler (M) sektörlerinde ücret dağılımları diğer sektörlere nazaran daha eşit dağılımdadır. İmalat (C) sektörü için hem üretim değerleri hem de faktör maliyetlerine göre katma değerleri eşitsizlik seviyesini gösteren Gini değerleri 0,985 olarak hesaplanmıştır. Oldukça yüksek olan bu değer, sektörde girişim grupları arasında üretim değeri ve katma değer açısından ciddi eşitsizliklerin göstergesidir. Sektör içi eşitsizliklerle sektörler arası eşitsizlikleri karşılaştırabilmek amacıyla çalışan sayısı, ödenen ücretler, üretim değeri ve katma değer göstergelerinin Gini değerleri aritmetik ortalamaları sırasıly 0,4383 0,6012 0,5161 ve 0,5711'dir. Bu değerler, çalışan sayısı ve ücretlerde sektör içi eşitsizliklerin, üretim değeri ve katma değerde ise sektörler arası eşitsizliklerin daha yüksek olduğunu kanıtlamaktadır.

Tablo: 6

Korelasyon Analizi

\begin{tabular}{|c|c|c|c|c|c|c|c|c|}
\hline & & $\begin{array}{l}\text { Bilgisayar } \\
\text { Kullanımı }\end{array}$ & $\begin{array}{c}\text { İnternet } \\
\text { Kullanımı }\end{array}$ & $\begin{array}{c}\text { Web } \\
\text { Sahipliği }\end{array}$ & $\begin{array}{c}\text { Çalışan } \\
\text { Sayısı }\end{array}$ & Ücret & $\begin{array}{l}\text { Üretim } \\
\text { Değeri }\end{array}$ & $\begin{array}{l}\text { Katma } \\
\text { Değer }\end{array}$ \\
\hline $\begin{array}{l}\text { Bilgisayar } \\
\text { Kullanımı }\end{array}$ & Correlation Coefficient & 1,000 & & & & & & \\
\hline & $\begin{array}{l}\text { Sig. (2-tailed) } \\
\mathrm{N}\end{array}$ & 10 & & & & & & \\
\hline $\begin{array}{l}\text { İnternet } \\
\text { Kullanımı }\end{array}$ & Correlation Coefficient &, $988(* *)$ & 1,000 & & & & & \\
\hline & $\begin{array}{l}\text { Sig. (2-tailed) } \\
\mathrm{N}\end{array}$ & $\begin{array}{c}, 000 \\
10\end{array}$ & 10 & & & & & \\
\hline $\begin{array}{l}\text { Web } \\
\text { Shipliği }\end{array}$ & Correlation Coefficient &, $\mathbf{8 3 0}(* *)$ &, $842(* *)$ & 1,000 & & & & \\
\hline & $\begin{array}{l}\text { Sig. (2-tailed) } \\
\mathrm{N}\end{array}$ & $\begin{array}{c}, 003 \\
10\end{array}$ & $\begin{array}{c}, 002 \\
10\end{array}$ & $\dot{10}$ & & & & \\
\hline $\begin{array}{l}\text { Çalışan } \\
\text { Sayısı }\end{array}$ & Correlation Coefficient & ,794(**) & ,782(**) &, $891(* *)$ & 1,000 & & & \\
\hline & $\begin{array}{l}\text { Sig. (2-tailed) } \\
\mathrm{N}\end{array}$ & $\begin{array}{c}, 006 \\
10\end{array}$ & $\begin{array}{c}, 008 \\
10\end{array}$ & $\begin{array}{c}, 001 \\
10\end{array}$ & 10 & & & \\
\hline Ücret & $\begin{array}{l}\text { Correlation Coefficient } \\
\text { Sig. (2-tailed) } \\
\text { N }\end{array}$ & $\begin{array}{c}, \mathbf{6 9 7}(*) \\
, 025 \\
10\end{array}$ & $\begin{array}{c}, \mathbf{6 8 5}(*) \\
, 029 \\
10\end{array}$ & $\begin{array}{c}, \mathbf{7 8 2}(* *) \\
, 008 \\
10\end{array}$ & $\begin{array}{c}, \mathbf{9 0 3}(* *) \\
, 000 \\
10\end{array}$ & $\begin{array}{l}1,000 \\
. \\
10\end{array}$ & & \\
\hline $\begin{array}{l}\text { Üretim } \\
\text { Deăeri }\end{array}$ & Correlation Coefficient & 479 &, 515 &, $648(*)$ &, $806(* *)$ &, $855(* *)$ & 1,000 & \\
\hline & $\begin{array}{l}\text { Sig. (2-tailed) } \\
\mathrm{N}\end{array}$ & $\begin{array}{l}, 162 \\
10\end{array}$ & $\begin{array}{c}, 128 \\
10\end{array}$ & $\begin{array}{c}, 043 \\
10\end{array}$ & $\begin{array}{c}, 005 \\
10\end{array}$ & $\begin{array}{l}, 002 \\
10\end{array}$ & 10 & \\
\hline $\begin{array}{l}\text { Katma } \\
\text { Değer }\end{array}$ & Correlation Coefficient & ,479 &, 515 & ,588 &, $745(*)$ & ,782(**) &, $891(* *)$ & 1,000 \\
\hline & $\begin{array}{l}\text { Sig. (2-tailed) } \\
\mathrm{N}\end{array}$ & $\begin{array}{c}, 162 \\
10\end{array}$ & $\begin{array}{c}, 128 \\
10\end{array}$ & $\begin{array}{c}, 074 \\
10\end{array}$ & $\begin{array}{c}, 013 \\
10\end{array}$ & $\begin{array}{c}, 008 \\
10\end{array}$ & $\begin{array}{c}, 001 \\
10\end{array}$ & 10 \\
\hline
\end{tabular}


Tablo 5'de hesaplanan Gini değerleri arasında anlamlı ilişkilerin belirlenmesi için yapılan korelasyon analizi Tablo 6'da verilmiştir. Hesaplanan Gini değerleri bazı değişkenlerde normal dağılım göstermemektedir. Değişkenlerde normal dağılım söz konusu olmadığında korelasyon analizinin Sperman testi ile yapılması önerilmektedir (Mukaka, 2012; Tabachnick ve Fidell, 2013). Spearman korelasyon analizi ile elde edilen katsayılar, bilgisayar kullanımı, internet kullanımı ve web sayfası sahipliği ile ilgili eşitsizlikler arasında pozitif anlamlı ilişki olduğunu göstermektedir. Bilişim sistemleri kullanımlarında görülen eşitsizliklerin, birbirleriyle yüksek düzeyde ilişkili olduğunu ortaya koymaktadır. Bilişim sistemleri içinde en yüksek ilişki bilgisayar ve internet kullanım farklılıkları arasındadir.

Sektör içi görülen sayısal bölünmenin, çalışan sayıları ve ücret eşitsizlikleri ile anlamlı ilişkisi bulunurken, üretim değeri ve katma değer farklılıklarıyla anlamlı ilişkisi bulunmamaktadır. Sayısal bölünme ile en anlamlı ilişkiye sahip olan gösterge, çalışan sayısı eşitsizlikleridir. Web sayfası sahipliğinin, çalışan sayısı ve ücretlerin yanı sıra üretim değeri eşitsizlikleriyle de anlamlı ilişkisi vardır.

Çalışan sayısı, ücretler, üretim değeri ve katma değer göstergeleri açısından sektör içi eşitsizlikler arasında kuvvetli pozitif anlamlı ilişki bulunmaktadır. En kuvvetli ilişki ücret eşitsizlikleri ile çalışan sayıları farklılıkları arasında görülmektedir. Sektördeki gruplar arasında çalışan sayısı farklılıklarının artması, sektör içi ücret eşitsizliklerinin de artmasına neden olmaktadır. Bilişim sistemleri kullanım farklılıklarıyla anlamlı ilişkisi bulunmayan faktör maliyetine göre katma değer eşitsizlikleri, çalışan sayısı, ücretler ve üretim değerleri ile pozitif ilişkiye sahiptir. Faktör maliyetlerine göre katma değer ile en kuvvetli ilişkiye sahip göstergenin ise üretim değeri olduğu görülmektedir.

\section{Sonuç}

Ekonomik yapıyı etkileyen başlıca unsurlar arasında gelen sektörel farklılıkları ortaya koymak için sektörel faaliyetlerin yanı sıra teknolojik göstergeler de kullanılmaktadır. Sektörel yapı farklılıklarından dolayı bazı sektörlerde teknolojinin yerleşmesi ve gelişmesi daha kolay olurken, bazı sektörlerde süreç yavaş ilerlemektedir. Teknolojik farklılıkların artmasına neden olan bu durum, sektörel eşitsizliklerin artmasına neden olmaktadır. $\mathrm{Bu}$ bağlamda çalışmada sektörel faaliyetlerle ilişkili olan çalışan sayısı, ücretler, üretim değeri ve faktör maliyetlerine göre katma değer göstergeleri ile girişimlerde kullanılan bilişim sistemleri olan bilgisayar kullanımı, internet kullanımı ve web sayfa sahipliğinde görülen farklılıkların analizi gerçekleştirilmiştir. Çalışmada eşitsizlik seviyelerini belirlemek için Gini yaklaşımı kullanılarak, sektörler arası ve sektör içi farklılıkları gösteren Gini değerleri hesaplanmıştır.

Gini değerlerine göre sektörler arası ve sektör içi bilişim sistemleri kullanım farklılıkları oldukça düşüktür. Gini değerlerinin sıfıra yakın olması hem sektör içi hem de sektörler arasında sayısal bölünmenin olmadığını göstermektedir. Bilişim sistemleri kullanım farklılıklarını gösteren sektörler arası Gini değerleri, sektör içi Gini değerlerinden daha yüksektir. Başka bir deyişle sektörler arası sayısal bölünme daha yüksek seviyeye 
sahiptir. Bilişim sistemlerinde hem sektör içi hem de sektörler arası görülen en yüksek sayısal bölünme web sayfası sahipliğindedir.

Çalışan sayısı, ücretler, üretim değeri ve faktör maliyetlerine göre katma değer eşitsizliklerinin Gini değerleri, bilişim sistemlerinin aksine, daha kötü bir tablo ortaya koymaktadır. Söz konusu göstergeler açısından Türkiye'de sektörler arası ve sektör içi ciddi eşitsizlikler tespit edilmiştir. Özellikle üretim değerleri ve katma değerde görülen eşitsizlik seviyeleri tam eşitsizlik düzeyine yakındır.

Bilişim sistemleri ve sektörel faaliyetlerle ilgili ilişkileri belirlemek amacıyla gerçekleştirilen sektör içi eşitsizliklerin korelasyon analizine göre bilgisayar kullanımları, internet kullanımları ve web sayfa sahipliği eşitsizlikleri arasında pozitif anlamlı ilişki vardır. En yüksek ilişki ise bilgisayar ve internet kullanım farklılıkları arasındadır. Benzer şekilde çalışan sayıları, ücretler, üretim değeri ve katma değer arasında pozitif anlamlı ilişki söz konusudur.

Bilgisayar ve internet kullanımlarındaki eşitsizlikler, çalışan sayıları ve ücret farklılıkları ile ilişkilidir. Başka bir deyişle çalışan sayıları ve ücretler arasındaki eşitsizliklerin fazla olduğu sektörlerde bilgisayar ve internet kullanımları arası eşitsizlikler de yüksektir. Diğer taraftan, bilgisayar ve internet kullanım eşitsizliklerinin üretim değeri ve katma değer eşitsizlikleri ile anlamlı ilişkisi bulunmamaktadır. Ancak web sayfa sahipliğinde görülen eşitsizlikler ile çalışan sayısı ve ücret eşitsizliklerinin yanı sıra, üretim değeri eşitsizlikleri arasında anlamlı pozitif ilişki olduğu tespit edilmiştir.

Araştırmada girişimlerin bilişim teknolojileri açısından hem sektör içi hem de sektörler arası en yüksek sayısal bölünmenin web sayfası sahipliğinde olduğu ortaya konulmuştur. $\mathrm{Bu}$ çerçevede girişimlerin e-ticaret yapabilmeleri açısından web sayfası sahipliliklerinin teşvik edilmesi ve gerekli bilgilendirmelerin yapılması önem arz etmektedir. Özellikle üretim değerinin yüksek olduğu imalat sektöründeki girişimlerin web sayfası sahiplilikleri ile ilgili eşitsizliklerinin giderilmesi için eğitim ve seminerleri içeren politikaların geliştirilmesi yerinde olacaktır. Ayrıca sektör içi eşitsizliklerde küçük işletmelerin gördüğü zararın azaltılması için bu girişimlere yönelik teşvik politikalarının uygulanması gerekir. Diğer taraftan ulaştırma ve depolama, konaklama ve yiyecek hizmeti faaliyetleri, bilgi ve iletişim, gayrimenkul faaliyetleri, mesleki, bilimsel ve teknik faaliyetler gibi hizmet sektörlerinde bilişim sistemleri kullanımı, çalışan sayısı, ücretler, katma değer ve üretim değerleri açısından sektör içi eşitsizlikler yüksek değildir. Ancak Tablo 2'de sunulduğu üzere, katma değer ve üretim değerlerinin diğer sektörlere nazaran oldukça düşük olduğu görülmektedir. Bu durum TÜİK raporlarındaki eksik verilerden kaynaklanabileceği gibi hizmet sektöründeki kayıt dışı işlemlerden de kaynaklanabilir. Bu çerçevede özellikle hizmet sektöründen verilerin elde edilmesinde daha sağlıklı yolların belirlenmesi ve kayıt dışılığın önlenmesi amacıyla mali kontrol mekanizmalarının gözden geçirilmesi gerekliliktir.

Çalışmada sektörler arası ve sektör içi eşitsizlik seviyeleri, Tüik tarafından yayınlanan raporlarda yer alan bazı göstergelerden yararlanılarak ortaya konulmuştur. 
Kullanılan göstergelere e-ticaret, sosyal medya kullanımları ile ARGE, sosyal güvenlik ve yatırım harcamaları gibi değişkenler eklenerek, çalışmanın kapsamı genişletilebilir. Analiz sadece 2013 yılı verileri ile yapılmıştır. Sonraki çalışmalarda ise daha önceki yıllara ait sektörel verilerin derlenmesi ile eşitsizliklerin yıllara göre durum analizi gerçekleştirilebilir.

\section{Kaynaklar}

Acemoglu, D. (1998), "Why Do New Technologies Complement Skills? Directed Technical Change and Wage Inequality", The Quarterly Journal of Economics, 113(4), 1055-1089.

Angel, U. \& K.D. Tanabe (2012), "Micro Determinants of Informal Economy in the Middle East and North Africa Region", Social Protection and Labor: The World Bank, SP Discussion Paper, No: 1201.

Atkinson, A. (1970), “On the Measurement of Inequality”, Journal of Economic Theory, 2, 244-263.

Autor, D.H. \& L.F. Katz \& A.B. Krueger (1998), "Computing Inequality: Have Computers Changed the Labor Market?", The Quarterly Journal of Economics, 113(4), 1169-1213.

Berman, E. \& J. Bound \& S. Machin (1998), "Implications of Skill-Biased Technological Change: International Evidence", The Quarterly Journal of Economics, 113(4), 1245-1279.

Blais, A. \& D.E. Blake \& S. Dion (1990), "The Public/Private Sector Cleavage in North America”, Comparative Political Studies, 23, 381-403.

Çelik, O. \& S. Selim (2014), “Türkiye'de Kamu ve Özel Sektör Ücret Farklılıklarının Kantil Regresyon Yaklaşımı ile Analizi”, Yönetim ve Ekonomi, 21(1), 205-232.

Ceriani, L. \& P. Verme (2012), "The origins of the Gini index: extracts from Variabilità e Mutabilità (1912) by Corrado Gini”, J Econ Inequal, 10, 421-443.

Chakraborty, J. \& M.M. Bosman (2005), "Measuring the Digital Divide in the United States: Race, Income and Personel Computer Ownership", The Professional Geographer, 57(3), 395410.

Cowell, F.A. \& S.P. Jenkins (1995), "How Much Inequality Can We Explain? A Methodology and an Application to the United States", The Economic Journal, 105(429), 421-430.

Currie, W.L. (1996), "Organizational structure and the use of information technology: Preliminary findings of a survey in the private and public sector", International Journal of Information Management, 16(1), 51-64.

Deininger, K. \& L. Squire (1998), "New ways of looking at old issues: inequality and growth", Journal of Development Economics, 57, 259-287.

Dickens, W. \& L. Katz (1987), "Interindustry Wage Differences and Industry Characteristics", NBER Working Paper, 2014, Cambridge, Mass.

Dreher, A. \& N. Gaston (2008), "Has Globalization Increased Inequality?", Review of International Economics, 16, 516-536.

Elveren, A.Y. \& J.K. Galbraith (2009), "Pay Inequality in Turkey in the Neo- Liberal Era, 19802001", European Journal of Comparative Economics, 6(2), 177-206.

Filiztekin, A. \& M.A. Çelik (2010), “Türkiye'de Bölgesel Gelir Eşitsizliği”, Megaron, 5(3), 116-127.

Freeman, R. (1995), “Are Your Wages Set in Beijing?”, The Journal of Economic Perspectives, 9, $15-32$.

Galbraith J.K. \& T. Hale (2007), "Between-Sector Earnings Inequality in the United States", UTIP Working Paper, 43. 
Goodman, L.A. \& W.H. Kruskal (1959), "Measures of Association for Cross Classifications. II: Further Discussion and References", Journal of the American Statistical Association, 54(285), 123-163.

Gürdal, O. (2004), “Bilgi Ekonomisi ve/veya Yeni Ekonomi’nin Reddettikleri”, Bilgi Dünyası, 5(1), 48-73.

Hoffmann, F. \& S. Shi (2013), Sectoral Shift, Job Mobility and Wage Inequality, <https://www.economicdynamics.org/meetpapers/2014/paper_123.pdf>, 20.12.2015.

Ilgın, Y. (1995), “Kayıtdışı Ekonomi ve Türkiye'deki Boyutları”, Uzmanlık Tezi, DPT, Ankara.

Kakwani, N.C. (1977), “Applications of Lorenz Curves in Economic Analysis”, Econometrica, 45(3), 719-728.

Karluk, S.R. (2005), Cumhuriyetin Illanından Günümüze Türkiye Ekonomisinde Yapısal Dönüşüm (10. Bask1), İstanbul: Beta Yayınevi.

Karoly, L.A. (1992), "Changes in the Distribution of Individual Earnings in the United States: 19671986", The Review of Economics and Statistics, 74(1), 107-115.

Kraftova I. \& Z. Mateja \& P. Prasilova (2011), "Economic Performance: Variability of Businesses within Each Industry and Among Industries", Inzinerine Ekonomika-Engineering Economics, 22(5), 459-467.

Kuznets, S. (1955), "Economic growth and income inequality", American Economic Review, XLV, $1-28$.

Love, P.E.D. \& Z. Iranib \& C. Standinga \& C. Lina \& J.M. Burn (2005), "The enigma of evaluation: benefits, costs and risks of IT in Australian small-medium-sized enterprises", Information \& Management, 42, 947-964.

MacLachlan, I. \& R. Sawada (1997), "Measures of Income Inequality and Social Polarization in Canadian Metropolitan Areas", The Canadian Geographer / Le Ceographe Canadien, 41(4), 377-397.

Mahler, V. (2004), "Economic Globalization, Domestic Politics, and Income Inequality in the Developed Countries", Comparative Political Studies, 37, 1025-1053.

Melnikas, B. (2011), "Knowledge Economy: Synergy Effects, Interinstitutional Interaction and Internationalization Processes", Inzinerine Ekonomika-Engineering Economics, 22(4), 367-379.

Moriones, A.B. \& F.L. Lopez (2007), “A firm level analysis of determinants of ICT adoption in Spain”, Technovation, 27, 352-366.

Mukaka, M.M. (2012), "A guide to appropriate use of Correlation coefficient in medical research", Malawi Med J., 24(3), 69-71.

Ngai, L.R. \& C.A. Pissarides (2007), "Structural Change in a Multisector Model of Growth", The American Economic Review, 97(1), 429-443.

OECD (2000), The Service Economy, OECD Publishing.

OECD (2001), Understanding the Digital Divide, OECD Publishing.

OECD (2008), Growing Unequal?: Income Distribution and Poverty in OECD Countries, OECD Publishing.

OECD (2011), Divided We Stand: Why Inequality Keeps Rising, OECD Publishing.

Öztürk, L. \& İ. Aktar (2009), "Karadeniz Bölgesi İllerinde Kamu Tarım Yatırımları Dağılımının Gini Katsayısı İle Ölçülmesi”, Karadeniz Araştırmaları, 6(21), 113-122. 
Öztürk, L. (2012), “Türkiye'de Bölgesel Eşitsizliğin Sektörel Dinamikleri: Bir Ayrıştırma Analizi, 1987-2001”, Ege Akademik Bakış, 12(2), 149-159.

Porter, M.E. \& V.E. Millar (1985), "How information gives you competitive advantage", Harvard Business Review, 63(4), 149-160.

Samuelson, P. (1948), "International Trade and the Equalization of Factor Prices", Economic Journal, 58, 165-184.

Schettkat, R. \& L. Yocarini (2006), "The Shift to Services Employment: A Review of the Literature", Structural Change and Economic Dynamics, 17(2), 127-147.

Selim R. \& Ö. Günçavdı \& A.A. Bayar (2014), “Türkiye'de Bireysel Gelir Dağılımı Eşitsizlikleri: Fonksiyonel Gelir Kaynakları ve Bölgesel Eşitsizlikler”, Tüsiad-T/2014-06/554.

Shankar, R. \& A. Shah (2003), "Bridging the Economic Divide Within Countries: A Scorecard on the Performance of Regional Policies in Reducing Regional Income Disparities", World Development, 31(8), 1421-1441.

Stephenson, S. \& G. Hufbauer (2011), "Labor Mobility" in Chauffour, Jean-Pierre \& Maur, JeanChristophe (ed.), Preferential Trade Agreement Policies for Development - A Handbook, World Bank, Washington D.C., 275-306.

Summers, R. (1985), "Services in the International Economy", in R.P. Inman (ed.), Managing the Service Economy: Prospects and Problems, CUP, Cambridge: MA, 27-48.

Tabachnick, B.G. \& L.S. Fidell (2013), Using Multivariate Statistics (sixth ed.), Boston: Pearson.

Tansel, A. (2005), "Public-Private Employment Choice, Wage Differentials, and Gender in Turkey", Economic Development and Cultural Change, 53(2), 453-477.

Taştan, H. \& M. Akar (2013), “Türkiye İmalat Sanayiinde Bölgesel ve Sektörel Ücret Eşitsizliği”, Iktisat Fakültesi Mecmuast, 63(1), 17-49.

Thewissen, S. \& C. Wang \& O. Vliet (2013), "Sectoral trends in earnings inequality and employment International trade, skill-biased technological change, or labour market institutions?", LIS Working Paper Series Luxembourg Income Study (LIS), No: 595.

Toffler, A. (1980), The Third Wave, New York: Bantam Books.

Uppenberg, K. (2011), "Economic growth in the US and the EU: A Sectoral Decomposition", EIB Papers, 16(1), 18-51.

Vandermerwe, S. \& J. Rada (1988), "Servitization of business: Adding value by adding services", European Management Journal, 6(4), 314-324.

Van-Reenen, R. (2011), "Wage Inequality, Technology and Trade: 21st Century Evidence”, Labour Economics, 18, 730-741.

Van-Vliet, O. (2011), "Convergence and Europeanisation: The Political Economy of Social and Labour Market Policies", Dissertation, Leiden: Leiden University Press.

Winner, H. (2012), "Fiscal Competition and the Composition of Public Expenditure: An Empirical Study", Contemporary Economics, 6, 38-54.

Yamak, N. \& B. Tanrı̈ver \& F. Güneysu (2012), “Turizm - Ekonomik Büyüme İlişkisi: Sektör Bazında Bir İnceleme”, Atatürk Üniversitesi İktisadi ve İdari Bilimler Dergisi, 26(2), 205-220. 